\title{
Inkatha's young militants: reconsidering political violence in South Africa
}

\begin{abstract}
South Africa's township revolts have generated much excellent research on the central role played by rebellious, urban youth. This article explores a parallel set of intergenerational conflicts that opened up in the marginal rural districts of the Natal Midlands, which were exacerbated by apartheid's Forced Removals of labour tenants from commercial farming districts to crowded "Native Reserves" in the 1970s. At this time of deepening poverty, elders worried about the rising incidence of juvenile petty crime, particularly amongst the teenagers who increasingly took itinerant, seasonal labour on the commercial farms. Some of these young migrants, unable to find steady factory work at a time of mounting unemployment, also played a leading role in the illicit, sometimes criminal networks of South Africa's growing popular economy. Finally, I show how some of these youths were mobilised by Inkatha during the war against the African National Congress in Johannesburg often to the revulsion of older men who abhorred their socially harmful, thuggish violence, which spiralled uncontrollably along migrant routes. Thus the political violence was often known as the udlame: a brutal savagery that destroys households, communities and society.
\end{abstract}

\section{INTRODUCTION}

This paper explores the significance of the generational tensions that opened up in rural, migrant sending districts of South Africa from the 1970s onwards. "Rebellious youth" - an important aspect of African history, given that its societies have been structured by conflicts/relationships between generations (Abbink \& van Kessel 2005, Lindsay \& Miescher 2003, Waller 2006) - have already been thoroughly studied by historians of South Africa's cities. The historical importance of the township youth revolts and, more broadly, the country's brutal history of industrialisation and high rates of urban crime have given urgency to such research questions (Glaser 2008, Kynoch 2008). Typically, burgeoning cities are seen as a solvent to patriarchal control, creating new categories of youth groups, often described by worried elders as "delinquents". ${ }^{1}$ Yet for all this valuable research focused on the urban arena, South African crime statistics suggest that extremely high murder rates have long been found in many chieftaincy areas ${ }^{2}$ - indicating that similar questions about South Africa's rural youth deserve equal analytical attention to their better known township counterparts. 
This paper has three connected ambitions. One is to provide an account of the widening generational tensions in the poor, peripheral districts of the rural Natal Midlands in the 1970s and 1980s at a time of economic crisis when patriarchal households came under pressure. ${ }^{3}$ Rural youth associations, intergenerational conflicts and migrant gangs during the early $20^{\text {th }}$ C (e.g. Beinart 1991; Kynoch 2005) and the apartheid period (e.g. Delius 1994; McAllister \& Deliwe 1994; Mchunu 2007; Niehaus 2000) have been surveyed in some depth. Here I explore how the deep history of youth gangs and "juvenile delinquency" in the Natal Midlands, which was linked to a protracted process of rural dispossession (Bradford 1987), were exacerbated by apartheid's forced removals of labour tenants from commercial farming districts in the 1970s. I pay particular attention to the patterns of youthful migration/mobility that lay beyond the control of household heads. At this time of deepening poverty, elders worried about the rising incidence of juvenile petty crime, particularly amongst the bands of boys who increasingly took casual, itinerant, seasonal labour on the commercial farms. Some of the older teenagers and young men, unable to find steady factory work at a time of mounting migrant unemployment, also played a leading role in the illicit, sometimes criminal networks of South Africa's burgeoning popular economy. This was epitomised by the growth of the violently competitive, minibus-taxi industry, whose networks, centred on the cities of Durban and Johannesburg, were dominated by Zulu-speaking migrants. The rank-and-file of the minibus-taxi industry and its related, illicit trades, such as cattle rustling and car-jacking, were often young, marginal, migrant men. ${ }^{4}$ (Similar spatial patterns have been noted elsewhere on the continent - cf. Anderson 2002; Nolte 2004.) Consequently, the violence that gripped the peripheral districts of the Natal Midlands in the 1980s was popularly described as a crisis caused by the thuggish actions of delinquent youth. ${ }^{5}$ 
As much as patriarchal controls eroded while violence along migrant routes spiralled outwards in the 1980s, it is also important to note attempts that were made to rebuild social relationships. A second, interrelated theme considered in this article thus concerns the efforts made within the rural district of Msinga to mediate the complex conflicts - known as "faction-fighting" - of the 1980s: fights that were often linked to the criminal activities of small gangs of young men. ${ }^{6}$ For as much as institutions of chieftaincy came under pressure to the extent that men avoided nomination for office because of the dangers it brought - the ethical ideals of eldership were paradoxically even more valued during a time of discord.

Nonetheless, the 1980s was not a promising time for peace-building, given the mounting conflicts between the African National Congress (ANC) and Inkatha, the latter which particularly mobilised amongst Zulu-speaking migrants in Johannesburg. A third aim, therefore, is to broach broader questions concerning the political violence that accompanied South Africa's democratic transition. There is a rich literature that considers the generational fault lines that structured much of this violence. One strand of this research particularly emphasises the central role played by "township youth" and "schooled youth" as "vanguards and vandals" (e.g. Marks 2001, Seekings 1993). Another strand concerns the older generation of migrant labourers who often rallied to the chieftaincy against the ANC's Comrades (Bonner \& Ndima 1999; Bonner \& Nieftagodien 2001, 2008; Segal 1992). Hickel (2015) and Waetjen (2006) provide convincing accounts of why many of these older men joined the Inkatha Freedom Party, which promised to protect patriarchal privilege that was threatened by young ANC comrades. At the same time, we run the risk of oversimplifying the patterns of the political violence if we simply argue that IFP elders were ranged against ANCsupporting youth. Indeed, a number of contemporaneous accounts noted the important role played by young militants within Inkatha's ranks - often to the revulsion of older migrants 
who abhorred their thuggish violence (Ndlovu 1994; Xeketwane 1991, 1993). ${ }^{7}$ Thus a focus on young delinquents helps us understand how the confused, uncontrolled patterns of political violence, which spread so rapidly along migrant routes across the region, was so often known as the udlame - a brutal savagery that destroys social relationships.

\section{POVERTY, PILFERING AND THE PLANTATIONS}

Across Africa 'youth may have begun earlier and lasted longer' as a consequence of the disruptions of colonialism (Waller 2006: 81). Certainly, this was the case in the settler farming districts of the Natal Midlands of South Africa, where a long history of youth gangs and intergenerational tensions is linked to a protracted history of rural dispossession. Bradford (1987) and McClendon's (2002) work reveals how the expansion of commercial agricultural production in the Natal Midlands during the 1920s and 1930s placed immense strain on African labour tenant households, with women, children and, most notably, youths forced to provide more labour to the settler farmers. Bands of youths became a potent force in the Midlands, particularly in the district of Weenen, which had particularly high numbers of labour tenants. During the interwar years, young iigosa in Weenen district were transformed "from leaders of dance associations to "generals"" elected by their peers. On the weekends rival igosa would 'lead their armed detachments to weddings and beer drinks where "factionfights" often erupted' (Bradford 1987: 46). Their activities sometimes caused great disquiet amongst the chiefs who nominally held authority over the tenants living the white farms. ${ }^{8}$

In this section I explore how these long-standing intergenerational tensions in the Natal Midlands were exacerbated by apartheid's forced removals - a process that would see 
1.1 million labour tenants across South Africa evicted from the farms. According to a contemporary account:

In September 1969, police helicopters flew over [Weenen district] ...picking up any men who could be found at home, on footpaths, or ducking under bushes to hide. Their arrest and subsequent trial at a special court at Weenen marked the beginning of Forced Removals in a district which has a notorious place in Natal's agricultural history. $^{9}$

Thus came 'the mixed up period' when, over the course of a few years, perhaps 20,000 African labour tenants were forced off the commercial farms of Weenen into the neighbouring district of Msinga, which fell under the KwaZulu Homeland Authorities. This was a time when once moderately prosperous labour tenants - migrants who had kept cattle and ploughed their own land on the Weenen farms, whilst working in South Africa's cities lost the cattle that made them men; when their livestock 'went to the speculators at knockdown prices'. The Removals also led to social dislocation and conflict: 'a time of great thieving', as 'poverty and the rising cost of food forced many people who cannot get jobs to find that stock-theft and dagga [cannabis] growing are a secure way of making a living,. ${ }^{10}$

The Alcock family, the founders of the Church Agricultural Project, as had come to Msinga in 1973 hoping to support smallholder-farming. Their newsletters provide a finely wrought account of the divide between an older generation of labour tenants who had ploughed Weenen's land and a younger generation who would have a very different relationship to the land and rural livelihoods in Msinga. Older men and women were well versed in natural lore; they could name dozens of grasses - 'intunga, mlalatensha, 
uqambalala, ubabe, ingongoni, imbuthane, isinandi, imbanjane, umsingizane' - each with different characteristics and uses. ${ }^{11}$ But most young boys had little detailed knowledge of and interest in these matters, given that they had little hope of putting a plough to the ground. The Alcocks worked closely with some of these older men, such as Seliswe Dladla, a migrant worker who laboured on Johannesburg's construction sites for R50 a month, yet had been a man of substance, with fifty cattle, one hundred goats, two wives, when he lived as a labour tenant on Weenen's farms. The forced removals had been disastrous, his cattle and iron plough bought at a discount by speculators. ${ }^{12}$ Surveys conducted by the Surplus People Project at Sahlumbe, a settlement at the entrance of the Mashunka valley of Msinga, confirmed such accounts. Of the households surveyed, 93\% had grown crops when they lived on the "white farms" at Weenen; now not one had a field. Moreover, Msinga was a thornveld district lying in a rain shadow. The 1955 Tomlinson Commission estimated that here a black smallholder farmer required 83 hectares and sixteen cattle to make a living. Following the relocations, average land-holdings in the district were 1.6 hectares per person - 'much of this stony hillside'. ${ }^{13}$ Nonetheless, many from the older generation remained keen to make some sort of a livelihood from the land, and participated in the initiatives of the Church Agricultural Project. 'We are men again! At last our hands can feel the hair of living cattle!' they jubilated as they drew an ox-plough across the Church Agricultural Project's farm. 'How funny we are making a noise about what was once an ordinary thing., 14

The dissolution of the patriarchal homestead and authority during the apartheid era is also strongly evoked by a trade union researcher, Paul Stewart, who visited rural homesteader M.X. recently retrenched from a factory, in the neighbouring district of Nqutu. The other crisis falling on migrant households across South Africa at this time was the decline of unskilled, blue collar work as, from the mid-1970s onwards, 'the economy simply grew too 
slowly to keep up with growth in the labour force' (Planning Commission 2011). M.X. was among the 100,000 unskilled workers laid off from the metal industry in the early 1980s. Paul journeyed to Nqutu to find himself pitched into the middle of a family crisis. M.X.'s second wife had recently absconded along with eight young children. 'Quiet - don't let the secret out,' an older sibling gestured to another child who was talking to the researchers (Stewart 1981: 15, 17). Other family members, too, were evading M.X.'s patriarchal authority. Some openly complained that M.X. was too poor to provide Christmas presents. And whilst his first wife deferentially knelt whenever she addressed him, she would not reveal the whereabouts of another daughter who had also fled the family home. M.X. was eager to show off his oxen plough to his guests; yet he struggled to yoke these scrawny beasts that clearly had not been used as draught animals for some time.

What were the consequences of such scenarios of homestead dissolution for youth socialisation? Outwardly, childhood continued as before. Primary schooling arrived late in the poorest and most peripheral rural districts of South Africa - surveys suggested that well into the 1980 s only $30 \%$ of children in Msinga district attended school. ${ }^{15}$ Consequently bands of pre-pubescent boys spent much of their childhood outdoors, herding cattle. (Indeed, the district continued to hold relatively high numbers of goats and cattle.) ${ }^{16}$ Stick fighting remained the predominant sport: a means of testing oneself against friends and rivals, and a preparation for manhood. Gangs of boys - perhaps led by a champion stick-fighter (ingqwele) - enjoyed hunting mice and rabbits, which were barbequed and eaten in the veldt. Petty theft of small livestock such as chickens (considered women's possessions) was normally considered a boyish prank worthy of a thrashing rather than a crime ${ }^{17}$ In this sense, the forms and expressions of male socialisation that were seen in the 1970 s resembled the patterns that had been seen a generation earlier. 
At the same time, the poverty and "confusions" that had followed the forced removals gave these boyish escapades a sharpening edge. Studies across the Natal Midlands and nearby districts noted how the decline of smallholder production and the increasing circulation of purchased goods 'necessitated the reorganisation of household activities around a wide variety of income generating activities' (Mpanza \& Nattrass 1987: 23). Women knitted, sewed and sold their handcrafts. Msinga was very poor, even by rural South African standards, and at Mashunka young girls turned household chores into petty trades, for instance carrying loads of heavy loads of pilfered firewood into town for richer households. (They were paid with cabbage leaves.) ${ }^{18}$ These were the economic pressures that lay behind young boys' hunting, poaching, pilfering and scavenging.

In some households such boyish misadventures shaded into patterns of delinquent behaviour that lay beyond the control of the community. A medical mission in the neighbouring Nqutu district noted that every rural community had a handful of children who 'scrounged for food... and occasionally raided homes'. ${ }^{19}$ Take the Siwela brothers, aged eleven and twelve, who were running wild. 'Time and again they have been caught and returned to their grandfather who just cannot cope. They have been beaten for their misdemeanors... Their mother is in Durban and comes home only at Christmas; their father is unknown' (Clarke \& Ngobese 1975: 37). Likewise, legal sanction (such as it existed, for the few policemen allocated to Msinga district were busy running their own criminal rackets) held few fears for young children living hardscrabble lives. S.D. was 'the scrawny gang leader of all the naughty kids at Mashunka'. He had the rust coloured hair of kwashiorkor and had been the main breadwinner of his family since the age of seven, when his parents were killed in a stock-theft feud. 'He laid ambushes, fought, poached, trespassed and stole' and 
boasted 'about his latest escapades to make quite sure that everyone will know'. ${ }^{20}$ At one stage he briefly worked as a weekend errand boy at a trading store in the nearby town of Weenen, until he demanded his wages early and, when refused, stole a nearby bicycle in a moment of pique. He was locked up in the police station in Tugela Ferry town for a few days, until he was brought to court and punished with five lashes of the cane. 'How was it?' his gang asked when he returned. 'Kumnandi [sweet]... They bring you a cup of water and a slice of bread and you sit all day watching the policeman go past. ${ }^{21}$

More worrying for parents and elders were the vast numbers of boys and girls who absconded to do casual, togt labour on "the plantations" (i.e. the white farms). The household surveys undertaken by the Surplus People Project suggest that day and seasonal work on commercial farms became an increasingly important source of livelihoods in the Natal Midlands. ${ }^{22}$ Whilst Africans had worked on commercial farms since the early decades of the $20^{\text {th }}$ century, it is likely that flows of itinerant labour increased after the forced removals eradicated many African tenants from commercial farming districts. (One old man remembered: 'I never had to work on the plantations [i.e. white farms]... like all our children do today.' $)^{23}$ Increasingly, Weenen's white farmers sent lorries into Msinga in search of casual labour on a $100 \mathrm{~km}$ round journey each day. Others were hired for longer periods, particularly during the harvest months that required a glut of labour. They journeyed the length and breadth of Natal on the back of farmers' lorries. ${ }^{24}$ The numbers of youths taking seasonal work is difficult to obtain, for the apartheid government did not keep decent statistics on the subject. But campaigners' investigations suggested this practice was widespread across Natal, the Free State and Transvaal. ${ }^{25}$ 
Intriguingly, the children often went off to work on the commercial farms in small groups and gangs. Creina Alcock described S.D.'s band leaving in high spirits: it was a youthful rite of passage, one in which there was 'a bit of an adventure and a wage'. ${ }^{26}$ Another observer, a black clergyman, suggested that child labourers and their parents sometimes believed that 'the difficult life provided by farm work is maturing' (A.S.S. 1983: 18). We see this sense of joint purpose and pride in the remarkable group photo portraits of teenage farm workers held by the Killie Campbell Library in Durban: they proudly show off their best clothes, which they have presumably bought with wages earned from farm work. Indeed, roving photographers toured the commercial farming districts of the Natal Midlands, for teenage farm workers would pay for Polaroid portraits that they could send on to friends and lovers. $^{27}$

At the same time teachers, parents and elders feared that the deepening incidence of itinerant, togt labour meant youths were escaping adult control. 'Sex is free and all social conventions are broken... Vast numbers of children learned dagga smoking., ${ }^{28}$ Some farms were notorious for abuse. One young woman successfully sued for child maintenance after she was raped. Others were beaten: 'It's easier to sjambok a girl lying on a table than to whip them on the ground,' boasted another white farmer. ${ }^{29}$ It was also hungry work: 'the food was good - porridge, cabbage beans and some meat - but there was very little of it', remembered M.D. He worked on the farms aged ten, but fled after a year (Bond 1979: 19). The squalid living conditions endured by child labourers on South Africa's commercial farms are captured in the social realism of documentary photographers, whose gritty black-and-white portraits were exhibited by the London-based Anti-Slavery Society in the 1980s. Another elder explained: 'any child who had grown up in 'The Wilderness' [a common term used to describe the commercial farms] will be a trouble to society'. ${ }^{30}$ 


\section{IZINKABI - OXEN}

'I was asked what I want to be when I am big,' explained an Msinga youth when he was around fourteen years old (Bond 1979: 46). 'It is difficult to talk about the future. All I can say is that I want to be a MAN.' In their late teens young men (inisizwa) from Msinga travelled to South Africa's cities in search of a living, now that they were too old for seasonal farm labour, considered work for women and children. However, the paths that their fathers had taken towards manhood - steady "blue-collar" employment in the cities, which would allow them to marry and build their own homesteads on Weenen's farmlands - was blocked for this younger generation of migrants. This was the context in which some youths discovered that violent crime could provide a shortcut to a manhood and respect of sorts.

Heuristically, one might speak of three overlapping forms of illicit and often violently criminal activities that were linked to the transformation of patterns of migration/mobility. For one, a handful of transient young men organised themselves into impromptu gangs that engaged in crime sprees that brought them quick returns. The newsletters and reports of the Church Agricultural Project provide a vivid description of how the return of half-a-dozen young thugs from the migrant hostels of Johannesburg to Msinga sparked off an epidemic of cattle rustling and armed robberies. ${ }^{31}$ After each robbery the young men toured the neighbouring districts and rural townships, hurriedly selling off their booty, the only evidence that would convict them. They feasted on their stolen goods with girlfriends, "wives" and followers. After one robbery a witness saw S.X. driving down the valley, jubilantly stopping to tell everyone 'there was lots of money... and he would be buying meat and liquor to celebrate'. ${ }^{32}$ The brazenness with which such gangs operated shows how violent crime might 
reward young men with a brutal prestige of sorts. This was a fleeting fame, however - they would soon fleeing vigilante groups and police pursuers into the "tent towns" in neighbouring districts and the run-down migrant hostels and burgeoning squatter camps found in the big cities.

One reason why these young drifters operated with such impunity was because they hid in the cracks of the collapsing system of labour migrancy. From the mid-1980s onwards, as apartheid controls crumbled, new shack settlements emerged on the fringes of cities and small rural towns. Migration was no longer an oscillation between city and countryside; instead it became a tangled network of multidirectional movements (Potts 2010; Todes 2001). The decline of factory work also transformed the migrant hostels into slums. Radical researchers provided compelling contemporaneous accounts of the illicit and illegal activities that found haven in dilapidated hostel complexes, as they filled up with unemployed young men. 'Crews disguised as repair men... looted dormitory rooms'; disputes escalated into confrontations and stabbings (Sitas 1983: 266). ${ }^{33}$ Men pissed in bottles at night, for visiting a toilet was too dangerous. 'So much fighting, so much blood over nothing,' lamented one man. 'The Lord turned his gaze away in shame from the hostel, I am sure. There, the Devil has become king, and every man was becoming a tsotsi' (Sitas 1983: 267).

Young men were also at the forefront of the rise in faction-fighting that gripped many districts of the Natal Midlands in the 1980s. Msinga was infamous for these conflicts - the district 'surges and eddies with restlessness', noted an early newsletter of the Church Agricultural Project. 'When we arrived here in 1975 there was tension because Mvelase youths were helping themselves to Mtshali cattle and goats. Like all the jobless at Msinga, 
they had nothing to do all day, so rustling neighbours' stock was a game with a meal at the end of it. ${ }^{34}$ Elders put their fears starkly: 'Our sons do not want to work. They have learnt that pay is low, conditions are bad... They have found that theft brings better returns. Jail is not feared... These young men steal guns and bullets, which makes them lords at home. ${ }^{35}$

From the viewpoint of Msinga's elders, there were perhaps three reasons why young migrant men had become 'lords at home'. One was the close linkages between young men's pursuits, such as poaching and cattle rustling, and the burgeoning minibus-taxi industry whose owners raised capital by engaging in stock-theft and other criminal pursuits. South Africa's violently competitive, minibus-taxi industry has been well-documented. It became the main mode of transportation in the mid-1980s, as new webs of commuting and migration proliferated at a time apartheid patterns of spatial segregation collapsed (Gibbs 2014: 431-4). Its networks that centred on the cities of Durban and Johannesburg were often dominated by migrants from the Natal Midlands. ${ }^{36}$ As well as carrying passengers, minibus drivers trafficked other illicit goods. ${ }^{37}$ The multi-billion rand dagga growing trade was especially prevalent in the poor, peripheral districts of the Natal Midlands. ${ }^{38}$ The remote valleys were also centres of a roaring trade in stolen livestock. Stock-thieves were often car-jackers too, and Msinga's valleys were littered with the carcasses of vehicles that had been stolen in South Africa's cities. ${ }^{39}$ These multi-centred networks were suffused with the idioms of migrancy. Stolen vehicles were "skinned" in hidden valleys like stolen, slaughtered cattle. Men said they were piercing their ears (for the older generation of migrants had worn earplugs) when they bought a new minibus. ${ }^{40}$

A second (and related) element was that young men were at the forefront of a new, more brutal and criminalised form of faction-fighting that gripped Msinga in the 1980s: 'it is 
not the impi who are fighting... it's the izibengu - criminals, gangsters'. ${ }^{41}$ Clegg (1981) writes that, in the middle decades of the $20^{\text {th }}$ century, faction-fighting echoed contained rituals of stick-fighting: rival impi would publically assemble on a hill and ritually call each other out in 'a spectacle of violent confrontation'. Yet with the intensification of rural conflicts in the 1970s and 1980s faction-fighting was increasingly undertaken by well-armed war-parties that carried out assassination-type killings. Clegg describes these war-parties as amashinga (stick-fighters), a term that alludes to longer established patterns of youth socialisation and conflict. ${ }^{42}$ These fighters also acted as hired hit-men - colloquially known as izinkabi (oxen) in Johannesburg and KwaZulu/Natal - not least in the internecine feuds of the taxi industry. ${ }^{43}$ (A peace agreement signed in 2000 and posted of the office of the Weenen Taxi Association is telling: 'We will not attack and kill each other; we will not steal from each other; we will not kill each other's livestock; we will not damage each other's property; we will not intimidate, threaten or insult each other.') Thus there were close linkages between rural faction-fighting, illicit trades and criminal violence that spread along migrant routes from Msinga into the cities.

A third point is that the violence of young fighters was particularly disquieting because they broke established codes and conventions of warfare and flaunted gerontocratic controls. Elders complained that they were no longer respected; the conflicts were not the ritually contained, faction-fights of their youth. Although fights still started in longrecognisable ways - a stick-fight between rival dance teams; a dispute over land; stock-theft directed at a neighbouring clan - the violence of the war-parties then spiralled beyond control. ${ }^{44}$ Codes of war were ignored: 'People are killed even when they are hiding. You can't kill a man who is hiding from the fight. ${ }^{45}$ Geriatrics fled into the hills. Sometimes they hid with their drinking companions. At other times they were herded into crèches, guarded 
by younger fighters from their own clans from those of rivals. Extortion was also an integral part of faction-fighting, for provisioning a war party with guns and bullets and hiring transport (typically a minibus) was a costly business. Men who wanted no part in the fighting paid a fee and then disappeared into the shack settlements of South Africa's cities until the fighting was over. To pay the levies demanded by the gunmen, women for their part sold off their goats and took extra togt labour on the white farms. ('They [the gunmen] are wasting our bullets' Msinga women complained, when they heard fighters on the hillside loosing rounds into the night sky.) ${ }^{46}$ War also spilled from the hillsides into homesteads as fighters foraged for supplies, raided homes and held up vehicles, much like common criminals. And the fighters sometimes raped women - a violation of beliefs which held that for the safeguarding medicines to work the fighters must be purified by chastity. ${ }^{47}$

'Although the unrest in Msinga is conventionally blamed on disputes resulting from overpopulation and shortage of land, it has become increasingly clear to us that the root of most wars lay in the criminal activities of small gangs of young men,' concluded the Church Agricultural Project in the mid-1980s, during a spate of faction-fights. ${ }^{48}$ Their activities meant that "entire communities of hundreds of people are eventually embroiled in the trouble - drawn in unwillingly out of fear.' Another participant at a peace meeting stated the problem succinctly: 'it is the young men who are quarrelling. Only the young men can settle this. ${ }^{49}$

Msinga's elders worried that youths had become 'lords at home'; but the young men who fell into crime related to the burgeoning minibus-taxi industry take on a more forlorn appearance in Johannesburg's court records. Given that this industry was the main form of capital accumulation for black South Africans in the 1980s, a minority of prosperous vehicle owners 
became 'exemplars of patriarchal authority in South Africa's post-industrial, highly unequal society' (Gibbs 2014: 433). Successful taxi owners from the Natal Midlands bought township houses, practised polygyny, acquired pedigree hunting dogs, and kept large cattle herds. But they were in the minority: the industry, which often employed marginal, migrant youths, was also infamous for its fragmented, precarious working conditions.

Perhaps the image of an ox (inkabi) best encapsulates the struggles faced by young migrants working in this setting, and more generally trying to survive in the city. Many migrants used the epithet 'an ox perseveres' to describe the forbearance that was required to endure exhausting, casual labour and make a life in the squalid migrant hostels and shack settlements (Ndima 1997). ${ }^{50}$ Indeed, it is important to emphasise that many young men working in the taxi industry did not whole-heartedly embrace criminality, but rather found themselves drawn into the activities of violently competitive owners and rival associations. Working fourteen hours a day, for instance, taxi-rank marshals wielded whips as they herded commuters away from rival vehicles into their masters' minibuses (Barrett 2003; Bonner \& Nieftagodien 2008: 382). Similarly, minibus drivers, who were hired-and-fired on the spot, were beholden to bosses who sometimes used their young men as "foot soldiers" in the violent competition for new routes (Nkosi-Thomas \& Randera 2000).

At the same time, oxen are not simply draught animals eternally harnessed to a plough; many are admired and much loved for their proud, stubborn characters. ${ }^{51}$ Similarly, the young taxi drivers from the Natal Midlands working in Johannesburg took pride in their toughness and resilience. They muscled their way into township taverns, naming their tables naming their tables after the districts of the Midlands: 'Mahlabatini, Msinga [and] Nqutu'. ${ }^{52}$ They drank bottled beer; wore All Star trainers; permed their hair straight; and proposed love 
to sophisticated, perfumed, township women (for firewood-gathering rural women carry the smoky musk of open fires). They boasted and declaimed their exploits in Johannesburg, 'the city of the rambling mountains [the mine dumps], where women beat their husbands' (Xeketwane 1993: 154). And their hard-boiled commentary was the talk of the townships, for instance the bumper sticker that declared: 'Built From Genuine Stolen Parts' (Jijana 2013: 23). The tough-talking quips aimed at aloof township women who rode their vehicles was notorious too. Township youths explained why they dared not challenge the taxi drivers who insulted their girlfriends: 'even if you defeated him in a fair fight he would call his folks and you would have to flee. ${ }^{53}$

Moreover, a few oxen are champion fighters whose victories against rival bulls at the cattle dipping tanks are celebrated in the praise songs of herd boys (Mathaba 2000). Likewise, the izinkabi hired guns of the taxi industry 'elicited a certain wary reverence, not

just from their peers living in the migrant hostels, but from the township as a whole'.54 Indeed, in one trial the defendants explained why they had specifically sought out an inkabi from the migrant hostels: 'it was felt that Zulus were best suited for such violent action' (Daily Dispatch 26 August 1987). This was an ambivalent symbol of masculinity.

\section{THE RETICENCE OF ELDERSHIP}

As much as violence along the migrant routes spiralled outwards in the 1980 s, we should also note attempts within rural districts to bring these conflicts under control. Given that violence was often experienced as a generational crisis, it is not surprising that much effort focused on disciplining young delinquents and reincorporating dissonant parts back into the whole. 
Hence kin-based ideals of social cohesion were deeply treasured at a time of great social stress that undermined the authority of elders and chiefs.

One place to start is to note how elders, with limited success, sought to discipline individual "delinquents". As discussed above, the waning of established patterns of migrant labour and the chaotic living conditions inside migrant hostels allowed individual, transient thugs to avoid sanction. Nevertheless, elders made sporadic attempts to impose their authority. One Zulu man explained to researchers visiting a migrant hostel in Soweto how his nephew was stabbed to death by a homeboy in a dispute over a girlfriend. The fighting youths had been brought before elders, admonished and separated; but an unwitting Pedi neighbour later opened a door to the attacker, who struck with a knife. The killer 'is still around the hostel,' explained the uncle. 'We are not going to have him arrested; we will settle this thing in December [at a chief's court] at home' (Peskin \& Spiegel 1976: 28). Occasionally senior men living in the hostels took more direct action. In 1983 M.D. was 'chased out by the other hostel dwellers in an action so unprecedented that it was the talk of Mashunka valley'. ${ }^{5}$

By contrast, the documents of the Church Agricultural Project provide a detailed account of how a spate of robberies committed by a small band of young men across Msinga district in the mid-1980s was quashed by the resolute action of senior men. ${ }^{56}$ They formed hunting parties and went in search of the stolen goods and the thieves. They pointed guns at the outlaws and their associates and dragged them before chief's courts. Relatives suspected of harbouring the young men were threatened with banishment. Most importantly, police from Pietermaritzburg swept the district for guns - the first serious crackdown in years. Eventually, most of the youngsters were jailed for whatever offences could be pinned on 
them. Even those that escaped conviction were severely chastened, having been badly beaten during police interrogations.

More structured, well provisioned, vigilante groups also formed in response to the activities of organised gangs committing stock-theft and armed robbery in rural South Africa. In each of these instances, powerful senior men were at the heart of the response to criminal activities. Senior men living in the migrant hostels of Johannesburg's East Rand townships, for instance, told researchers how they had formed vigilante groups back in their Nqutu home district in response to the rising levels of stock-theft committed by taxi owners. Here it seems that key leaders were senior factory workers who were also involved in local Inkatha structures. ${ }^{57}$ At Mashunka Mountain, by contrast, vigilante bands were organised within local communities by isigodi and izinduna. ${ }^{58}$ One man was trekking home to Limehill with cattle bought at an auction in Msinga when he was accosted in a quiet gorge by a well provisioned band of men, 'all with guns and bullets', who demanded proof of ownership. The man hunted for the receipt in his pockets, 'speaking very meekly, as you do, when addressing a man with a gun'. The cattle had been legitimately bought, so the vigilantes 'took us home, gave us beer, and we slept there that night, as is the custom with travellers'. ${ }^{59}$

The larger faction-fights and local wars were even more fractious. Households and communities splintered as men scattered, hiding from the violence in the hills or the shack settlements of the cities. One murder could set off cycles of kin-based, vengeance killings (see Clegg 1981). The worst of the fighting choked the rural valleys. Rival factions set up roadblocks and ambushes that throttled the district's main arteries; they shot up the taxis 
belonging to their rivals and dragged men off buses, executing them alongside on the road. 'Now the roads are blocked the district has to cope with an unsettling mix of gossip and rumour, and snatches of news that can only add to the tension,' wrote the Church Agricultural Project during one Mashunka war. ${ }^{60}$

At the same time, we should also note the attempts to restore social communication and relationships. Whilst faction-fights became synonymous with sexual violence, they also gave prominence to senior women. Sometimes women provided a protective shield and safe passage for non-combatant men stranded in non-mans-land. They also used their moral authority to browbeat chiefs and izinduna into organising peace meetings. ${ }^{61}$ During one particular conflict the women from opposing sides even attended each other's funerals. This was a sensitive process, given the internecine divisions caused by violence. Distraught mourners sometimes refused reconciliation: 'Your husbands killed my father... And your sons also! Go! I don't want you!' Thus the groups of women from either side of the fighting warily kept apart, during the burial and the cleansing ceremonies, washing at separate pools in the mountain streams, waiting until young girls from the bereaved family brought over trays of tea and bread as a gesture of appeasement. ${ }^{62}$

Because the Church Agricultural Project had the only phone in the valley, their house was another important centre of correspondence and diplomacy. During one particularly vicious war, the phone would start ringing from 5am as migrant men illicitly called in from factory phones to check on their families. A cook at the huge Baragwanath Hospital in Soweto, who emerged as the 'diplomatic agent amongst those who had not run home,' called each day for a bulletin. ${ }^{63}$ Similarly, local magistrates might broadcast the news of a particularly important peace meeting through Radio Zulu - a radio station particularly 
popular amongst migrants because its programmes read out messages sent between families and friends.

A handful of senior izinduna, who commanded respect through force of personality, were perhaps the most important mediators. ${ }^{64}$ They bravely summoned groups of young fighters to their courts. Their gatherings were recognised as safe spaces for negotiations between rival factions. At the same time as war parties hunted their rivals across South Africa, these elders conducted shuttle diplomacy by taxi and bus, meeting fighters on a mountain top or a city hostel. Inevitably, after months of torturous dialogue, 'the guns sputter out'. Rituals of forgiveness and reconciliation, intended to bind the fighting men back into the wider body politic, would symbolise the peace accord. ${ }^{65}$ 'Then taxis are summoned to carry the breadwinners back to eGoli (the Reef/Johannesburg)'. Thus whilst faction-fighting increased in frequency and intensity in the 1980s, older ideals of eldership remained.

At the same time, we must note how kin-based violence corroded social authority. Eight izinduna were murdered on Mashunka Mountain in four years. ${ }^{66}$ 'It's no longer an honour in these parts to be selected an induna', noted Creina Alcock in another newsletter written in 1980. ${ }^{67}$ Three years later, Neil Alcock and four fellow members of a peace delegation would be ambushed and killed in the Church Agricultural Project's minibus when driving home from a courthouse mediation meeting, whilst trying to settle a conflict that had already claimed dozens of lives. Later, the hearings of the Truth and Reconciliation Commission in the Natal Midlands uncovered more instances in which peace monitors - men of authority, 
such as chiefs and clergymen - walked into murderous ambushes as they tried to mediate conflicts between rival clans and taxi associations. ${ }^{68}$

One reason that chiefly office brought such danger and exposure, which made mediation so difficult, was that social relationships were fragile and fluid. A transient son who had stolen and sold on building materials belonging to his uncle, for instance, might hold a family feast from the proceeds of another robbery six months later. ${ }^{69}$ Most significantly, as much as men of violence took lives and broke apart families, it was illicit, sometimes outright criminal activities that brought money into the poorest rural districts of the Natal Midlands. From an early age children in Mashunka were taught to 'be careful what they say' - not in the romanticised manner of Rudyard Kipling's Smuggler's Song, but because loose talk would bring killings into their homes. ${ }^{70}$ For in the mid-1980s, many of the men of substance and authority in Mashunka valley were making their money in South Africa's notoriously fractious, minibus-taxi industry, and its associated trades such as stock-theft. This foggy, 'grey area between licit and illicit enterprises, the paternal benevolence of the successful taxi owner who provides for neighbours and the kin based violence that permeates the industry' was remarkably difficult to navigate (Gibbs 2014: 446). Such fine grained moral sensibilities posed particular difficulties for izinduna who were expected to mediate disputes and judge cases brought before them. Moreover, most chiefs and headmen did not enjoy much in the way of government resources and support - the chief induna of the Mthembu clan, for instance, held his court cases in a rusting bus, the courthouse having been destroyed in a storm. Their authority was their word and little else. ${ }^{71}$

Consequently, some men refused nomination to traditional leadership. ${ }^{72}$ Another cautious induna in Msinga, for instance, cannily adjudicated tricky stock-theft cases by 
levying court fees on the plaintiff that were equal to the fines he demanded from the guilty parties, gaining a reputation for equivocation that kept danger from his door. ${ }^{73}$ The few izinduna on Mashunka Mountain who sought to uphold the authority of their office trod a lonely path. Sometimes they slept at home, when everyone else had fled into the hills, dangerously preserving their dignity and impartiality. These were 'reticent men, listeners, wary,' who chose their words carefully. ${ }^{74}$

\section{UDLAME - POLITICAL VIOLENCE, SOCIAL CHAOS}

As much as elders sought to mediate Msinga's conflicts, the final decade of apartheid was not a propitious moment for peacemaking. In July 1990 Mangosuthu Buthelezi, the Chief Minister of the KwaZulu Bantustan, launched the Inkatha Freedom Party (IFP) at a rally in the P.W.V - the city-region that sprawled across Pretoria Witwatersrand and Vereeniging provoking a spasm of violence across the city. In most of the 220 migrant hostels spread across the city IFP supporters seized control. These hostels became 'fortresses of fear': both sanctuaries for Zulu-speaking refugees fleeing their burnt-out, township homes, and also rallying points from which IFP militants mounted attacks on neighbouring townships (Segal 1992). 14,000 lives were consumed in the next four years - most in the P.W.V. region during a time of political violence that was commonly known as the udlame. This powerful word conveys social chaos: a violence that 'initiates a spiral of revenge attacks'; 'that opens the door to the violent resolution of many other [community and family] disputes... which might otherwise have ended peacefully (Peires 2000: 99; also Kelly 2015). The udlame had different sources and took various forms as it spread across South Africa. Here, I explore how the political violence that spiralled out of the migrant hostels of Johannesburg was entwined 
with and exacerbated by patterns of conflict associated with the criminality of uncontrollable young migrants.

Violence was concentrated in and around the migrant hostels, where older patterns of eldership had been unravelling for some time as industrial decline transformed them from factory dormitories into hubs of the taxi-industry and its related illicit trades. In 1990 there was a decisive rupture now a new wave of young migrants flooded into the dilapidated dormitories. One NGO was undertaking an upgrading project at Vosloorus Hostel when its residents, older men who had lived inside the hostel for decades, fled the violence. V.L., for instance, had been conscripted into an impi and forced to join the first clashes. A fortnight later he escaped for Orange Farm informal settlement, which was teeming with similar refugees. ${ }^{75}$ Such accounts are congruent with the research bravely conducted by Babylon Xeketwane $(1993: 41,43)$ in the migrant hostels of Soweto at the height of the violence. His snapshot surveys suggested that the majority of hostel residents were less than 30 years old; most had come to Johannesburg in 1990/91. There were even a few reports in the press (never proven) claiming that the IFP leadership was bussing in young men from rural districts notorious for faction-fighting. ${ }^{76}$

Ndlovu and Xeketwane's remarkable accounts emphasise the despair of the older generation at the criminality that the young migrants brought into the hostel. First, it seems that the age-set youth leaders, so important in the faction-fighting of the Natal Midlands, were often at the heart of the political mobilisation of the early 1990s. At Meadowlands hostel 'the inisizwa told us not to waste time but to arm ourselves. We took up arms and have not laid them down' (Xeketwane 1991: 28). At George Goch hostel the young leader (igosa) of the best dance troop in Bergville, a district that is almost as well known for its stock-theft 
and dagga smuggling as Msinga, played a central role in the fighting (Ndlovu 1994: 21). A second indicator of the transformation of the hostels was the influx of women - mainly refugees fleeing violence - into what had once been a male-only domain. In turn, hostels became notorious for the sexual violence: 'some [township women] come voluntarily whereas others are dragged against their will because they think they are smart. They think we are worth nothing because we are township rejects; that is why we drag them in kicking and screaming (Xeketwane 1993: 114). ${ }^{77}$ Third, township thugs fleeing vigilante justice often sought refuge in the hostels, falling in and making joint enterprise with the migrant stockthieves and carjackers. 'Cars are hijacked... girls are jack-rolled [raped at gunpoint]... attempts to seek peace were overridden... the younger generation had become uncontrollable' (Xeketwane 1993: 128).

At the same time we might note that many young migrants - the 'oxen' struggling to endure the city - also saw their fragile livelihoods and social networks shattered by the political violence. Two images of devastation recurred in a series of interviews concerning memories of this period that I conducted in 2011. One was the destruction of ethnicallycosmopolitan relationships. A man from Nqutu, for instance, explained how, having been conscripted into an impi, he fled his rented backyard shack for refuge in the migrant hostels, having first put his girlfriend and their child on a bus back to her mother in the northern Transvaal. He never saw her again. ${ }^{78}$ The second concerned the feuding within the minibusbus taxi industry, which not only destroyed lives and livelihoods but also brutally split the townships into rival routes and zones, further isolating those living in the hostels. ${ }^{79}$ Indeed, many migrant taxi drivers fled the hostels for the shack settlements of the city (Xeketwane 1993: 117): 'Life was unbearable for me... ... I was always scared that one day they [the passengers] would find out I was one of them [the hostel dwellers]. Besides, how do you kill 
your own customers?' Much as Msinga's war parties had dragged whole communities into faction-fights, many young men now found themselves sucked into the udlame.

Udlame savagery was not restricted to the hostels and townships. It also spread along migrant routes, devouring lives. Indeed, it was as hired muscle beholden to more senior political leaders and criminal bosses that some young migrants were inserted as hired guns into the spiralling political conflicts. Most infamous was the Nqutu Massacre of 1993 in which the kraal of an ANC-aligned traditional leader, Chief Joseph Molefe, was attacked by a gang of sixty masked men. Allegedly the gunmen were organised by Albert Mlaba, a township taxi owner and dealer of stolen cars, who had become close to the IFP leadership in the East Rand of the P.W.V. city-region after he supplied them with transport to attend political rallies. ${ }^{80}$ Violence also crossed political boundaries. Take the example of another feud transported along the transport corridors of KwaZulu Natal from city taxi ranks to the rural Bergville district. ${ }^{81}$ What made it so vicious was that rival taxi operators hailed from rival clans who were aligned to opposing political parties. The local induna and vicar who attempted to broker a peace deal at a series of public gatherings were themselves murdered by a young hit-man from the migrant hostels. The gunman claimed he was linked to an ANCaligned Self Defence Unit, and the killing was a political act; the judge ruled it was a criminal conspiracy. 'He [Rev. Izak Shandu] was a man who worked for peace,' noted the judge by way of brief tribute to one of the murdered peace monitors. ${ }^{82}$

The udlame likewise fed violence within Msinga in the early 1990s. 'Some of the change came from the accumulation of violence outside the valley. Some of the change came from the accumulation of war [and conflict] here at home,' explained Creina Alcock. 'Among the many deaths that have touched [the] Church Agricultural Project...' a white farmer from 
Dundee, murdered by three young carjackers; 'the fiancé of a member of staff... killed after he agreed to help an old man safeguard his pension from his son'; a teenage migrant necklaced [i.e. burned to death] by township Comrades; an adolescent and his parents whose homestead was attacked by stock-thieves. ${ }^{83}$

It was also during the udlame that S.D. ('the scrawny gang leader of all the naughty kids at Mashunka', mentioned in Section One) was shot dead. Now a young man, he may well have been embroiled in the political violence, for he had certainly been mixed up in criminal activities. A few years previously he had been 'hired to shoot a man, but didn't quite manage.' The Church Agricultural Project wrote him a short obituary:

An early death [was] not unexpected for a boy who had lived dangerously even when he was small... He may be remembered as the boy with kwashiorkor... [who] stole milk to feed his orphan brothers - a family of small criminals who managed to rear themselves after their parents were killed in bed for involving themselves in stocktheft.

\section{CONCLUSION}

South Africa's political violence and persistently high rates of violent crime have focused researchers' attention on the cleavages within society, not least generational conflicts between elders and young men. Much of the writing has focused on the ANC-supporting, township youths and Comrades who fought against Zulu-speaking migrant elders who supported Inkatha (Bonner \& Nieftagoiden 2001; Hickel 2015; Waetjen 2006). There have also been excellent studies of divides within rural districts that sometimes led to youth revolts against the chieftaincy (Delius 1996, Niehaus 2000). This article, focused on the districts of 
the Natal Midlands, has particularly emphasised how established forms of patriarchal authority were disrupted by changing forms of mobility. Historically, the Natal Midlands was well known for its youth gangs and faction-fighting; processes related to intergenerational conflicts that have followed rural dispossession. During the apartheid era there was an intensification and metamorphosis of these conflicts. Forced removals broke up the homes of labour tenant families; mounting industrial unemployment particularly affected unskilled migrant labourers. Thus migrant elders, whose authority had rested on building large homesteads, rich in cattle, wives and dependents, found themselves emasculated by these wrenching shifts in South Africa's political economy. At this 'time of confusion' and increasing poverty, youthful patterns of migration/mobility increasingly lay beyond the control of elders. Bands of boys fled family homes to take itinerant work on commercial farms. Small gangs of young men were also involved in the intensifying patterns of stocktheft and faction-fighting that accompanied the rise of the minibus-taxi industry. Indeed, the violently competitive minibus-taxi industry epitomised the burgeoning networks of the popular/informal economy.

Some young migrants played also a leading role in the udlame - the political conflicts, criminal violence and social chaos of the 1980s and 1990s - that uncontrollably spread along migrant routes. The political violence took various patterns in different regions. Here I have focused on the young men in the migrant hostels of the P.W.V. city-region who were conscripted into the ranks of Inkatha. Elsewhere, particularly in the areas around Richmond and Umbumbulu, gangs of young men fought for both the ANC and Inkatha. What was common to many of these conflicts was that patterns of political violence were often associated with the juvenile criminality of migrant gangs. It was these shape-shifting forms of violence - for instance the involvement of Albert Mlaba's city-based, car theft gang in a 
massacre that targeted supporters of an ANC-aligned chief - that made the udlame so brutal. In this instance, like many others, minibus-taxis carrying a well armed war-party transported violence along migrant routes.

Yet if much of this article gazes uncomfortably at the spectacle of youth violence, I also note attempts that were made to heal the body politic: the efforts of elders to stop Msinga's faction-fighting and the peace monitors who mediated South Africa's political violence. ${ }^{84}$ Likewise, if (a minority of) young men were the primary perpetrators of violence, young men tended to be its main victims too - and throughout the article I have drawn attention to the youths who found themselves sucked into the faction-fighting and political violence of the era. This article ends with the brutality and social chaos of the udlame; but we might also look beyond, at how patterns of post-apartheid peace-building have sought to resolve these conflicts, not least addressing the violence associated with young men. ${ }^{85}$

TIMOTHY GIBBS (t.gibbs@ucl.ac.uk) is a lecturer in African History at University College London and a Research Associate of the NRF Chair in Local Histories, University of Witwatersrand. This research was funded by the NRF Chair in Local Histories.

\footnotetext{
${ }^{1}$ Some accounts study how the migrant gangs that emerged in South Africa's cities were forged by the pressures of proletarianisation: for instance, Bonner 1987, van Onselen 1982, la Hausse 1990, Kynoch 2005. More recent studies emphasise the importance of youth socialisation within urban townships: Campbell 1992, Glaser 2000, Marks 2001, Morrell 2001.

${ }^{2}$ Apartheid statistics are very fragmented, but there were various indications that murder and other violent crimes rose significantly in the chieftaincy areas of South Africa in the early 1980s - see endnote forty-two. The maps produced by South Africa's Institute for Security Studies (n.d.) Crime Hub graphically show the very high rates of murder found in the rural districts of Transkei and KwaZulu throughout the 2000s.

${ }^{3}$ The core of my material comes from (and many intellectual debts are owed to) the newsletters of the Church Agricultural Project, based on the borders of Weenen \& Msinga districts. It is supplemented by interviews with migrants from Msinga, as well as documents from the TRC and other NGOs. Phil Bonner and Vusi Ndima's interviews with migrants from Msinga and the neighbouring Nqutu district in the mid-1990s, was also much
} 
appreciated. Finally, Peter Delius and Gerry Mare kindly pointed me towards Babylon Xeketwane's path-breaking dissertations $(1991,1993)$ and Duma Ndlovu's compelling journalism (1994) on Johannesburg's migrant hostels, which deserve special reference. ${ }^{4}$ There has been much excellent research on related topics. On faction-fighting see Clegg 1981; Malan 1990; Mathis 2013. On crime see Bank 1990; Bonner \& Ndima 1999; Kynoch 2005, 2013; Peires 1994; Smith 2015.

${ }^{5}$ We might speculate that similar processes were playing out in other rural regions of South Africa. In particular, newspapers make tantalising reference to a wave of faction-fighting and rural crime carried out by gangs of young men in districts such as Lusikiski in the early 1980s. Moreover, it seems that rural murder and stock theft rates rose in the 1970s and 1980 s - see endnote forty-two - provoking senior men to worry about a new generation of "delinquent youth".

${ }^{6}$ As Sithole (1998) notes, the blanket term "faction-fighting" can obscure more than it reveals. In this article I emphasise the criminal activities of small gangs of young men. ${ }^{7}$ Bank (2011) provides a fascinating, "mirror image", case study of the rural youth who played an important role within the ranks of the ANC-linked Comrades movement in the Eastern Cape city of East London.

${ }^{8}$ Beinart $(1990,1991)$ similarly notes the expansion of child/teenage labour on the sugar estates along the South Coast of Natal during the 1920s, during which indlavini gangs emerged in Mpondoland. La Hausse (1990) and Carton (2000) are excellent on an earlier generation of amalaita gangs, which emerged in Durban at the turn of the $20^{\text {th }} \mathrm{C}$ in the wake of the Bambatha rebellion.

${ }^{9}$ PC16/12 R. Alcock 'Report on Land Claims Programme' August 1995

${ }^{10}$ PC16/12, CAP Newsletter, March 1980

${ }^{11}$ PC16/12, CAP Newsletter, November 1985

12 PC16/12, CAP Newsletters, March 1980, May 1986

13 16/12, CAP Newsletter, January-February 1980

${ }^{14}$ 16/12, CAP Newsletter, February 1977

${ }^{15}$ Another survey reported in the Natal Witness (23 September 1983) suggested that only 4\% of residents at Sahlumbe had a Standard Six education. On rural education: Hartshorne (1992: 43, 128).

${ }^{16}$ PC16/12 'CAP's plans for 1985'; CAP Newsletter, November 1985.

${ }^{17}$ PC16/12, CAP Newsletters, August 1975, April 1977. Also: Bonner \& Ndima interview, K.N.

${ }^{18}$ PC16/12, CAP Newsletter, September 1975, May 1979, December 1979, April 1985.

Elsewhere: James (1983); Preston-Whyte \& Nene (1991: 229-42).

${ }^{19}$ More broadly: Murray (1980) Spiegel (1987) and van der Waal (1996).

${ }^{20}$ PC16/12, CAP Newsletters, August 1976, September 1978.

${ }^{21}$ PC16/12, CAP Newsletter, September, 1978

${ }^{22}$ File PC29/10/92 (Sahlumbe), AFRA, Alan Paton Centre, University of KwaZulu Natal, summarises the results of the survey. The original survey returns, which contain fascinating details, are found in the Killie Campbell library, Durban.

${ }^{23}$ PC16/12, CAP Newsletter, May 1986

${ }^{24}$ PC16/12, CAP Quarterly Report, December 1984- Feb 1985. CAP newsletters, January 1986, May-November 1986.

${ }^{25}$ The apartheid government's estimate that 60,000 child worked on commercial farms was a ridiculous undercount (A.S.S. 1983: 7). Post-apartheid government surveys have suggested figures around 120,000 (Bosch et al 2002). Close observers believe there has been a 
significant decline in child labour in commercial farming since 1994 - pers. comm. Creina Alcock, July 2015 - though I have found no statistics that confirm such observations.

${ }^{26}$ PC16/12, CAP Newsletter, March 1977

${ }^{27}$ Many thanks to Mwelela Cele and Nellie Somers who pointed me towards this display.

${ }^{28}$ PC16/12, N. Alcock to O. Dlomo, KwaZulu Minister for Education, 12 September/1978. Similar complaints were made in the labour tenant districts of Transvaal and the Eastern Cape: 'children are deserting school and home' (A.S.S. 1983: 28); 'parents do not know where their children are' (James 1983: 51). Intriguingly, it seems a contrasting pattern existed in the western districts of Transkei, where some children were controlled by black labour recruiters. These intermediaries included local chiefs, who took joining fees and demanded a portion of the children's wages; and black foremen and gang-masters, who travelled with their charges - cf. A.S.S. (1983: 28).

${ }^{29}$ PC16/12, CAP Quarterly Report, December 1984- Feb 1985

${ }^{30}$ PC16/12, CAP Newsletter, September 1977

${ }^{31}$ PC16/12, 'Background Report'; CAP Quarterly Report, August-November 1986. Also Malan (1990).

32 PC16/12, 'Background Report'.

${ }^{33}$ Also Peskin \& Spiegel (1976).

${ }^{34}$ PC16/12, CAP Newsletter, April 1980

${ }^{35}$ PC16/12, CAP members to Archbishop Hurley, (1980?)

${ }^{36}$ Although see Bank (1990) and Kynoch (2005) on the influential role played by Sothospeaking, Russian gangs in the minibus-taxi industry in the Free State and Johannesburg. ${ }^{37}$ On the circulation of weapons: PC16/12, CAP Newsletter, May 1983. Also: BAO, Box 5/22, File 109/1681, 'Minutes of Meeting 9/80 held at Ministers Chambers'

${ }^{38}$ PC16/12: CAP 'Directors Report, 15 February 1977. CAP Newsletters, particularly December 1976, March 1977, May 1980, January/February 1981. Also Streek \& Wicksteed (1981)

${ }^{39}$ On stock-theft: PC16/12, CAP Newsletters, especially November 1976, November 1978, May 1980. On car-jacking: PC16/12, CAP Quarterly Report, September 1992; CAP Annual Report, 2008-9.

${ }^{40}$ PC16/12, CAP Newsletter, September 1992. Fieldnotes, Msinga, January 2012.

${ }^{41}$ PC16/12, CAP Newsletter, June-August 1984. Discussions of rising murder rates in KwaZulu are found in the archives of the Department of Native Administration and Development (BAO), at the National Archives in Petoria, notably: Box 5/22, File 109/1681, Major C.J. Botes South African Police to Secretary for Justice KwaZulu, 14/8/80, and Secretary of Justice Ulundi to Director General, Department for Co-operation and Development, 13/10/80. On rising murder rates in Transkei: Transkei Legislative Assembly (1980: 413-22; 1981: .288-93; 1982: 332-6). Peires (1994) provides an excellent account of stock-theft in the Transkei districts.

${ }^{42}$ Interestingly, this term was not used or recognised by the men I interviewed in 2011 \& 2012, an indication, perhaps, of the fluidity of these practices (Pers. Comm. Creina Alcock, June 2015).

${ }^{43}$ The Ntsebeza Commission (2005: 53) into taxi violence in Cape Town found that migrant hit-men here were known as iimbovane (ants). Their fees in the mid-2000s were from R5,000 to R12,000.

${ }^{44}$ PC16/12, 'Report on proposed removal of Zwane Tribe, Msinga' March 1984; 'Itching for a fight', 1982; CAP Newsletter, April 1980

${ }^{45}$ PC16/12, CAP Newsletter, June-August 1984

${ }^{46}$ PC16/12, CAP Newsletter, June 1987 
${ }^{47}$ PC16/12, CAP Newsletter, June 1987. CAP 'Management Meeting Minutes', 11 April 1992.

${ }^{48}$ PC16/12, Report to Donors and CAP Trustees', 17 October 1983

${ }^{49}$ Ibid.

${ }^{50}$ Author interviews, M.Z., Soweto, 27 November 2011; M.M., Soweto, 27 November 2011; N.M., Soweto, 4 December 2011; S.M., Soweto, 4 December 2011. Author interviews: A.R, Mashunka, 3 January 2012; F.Z., Mashunka, 4 January 2012; G.C., Alberton, 2 August 2011. Seekings (2006) argues that researchers should pay more attention to "normal youth".

${ }^{51}$ Stories about much-loved oxen feature in some of the CAP newsletters - December 1976, February 1977, April 1980.

${ }^{52}$ Historical Papers, University of Witwatersrand, Hidden Voices interviews, G.M.N, 16 June 2004.

${ }^{53}$ Bonner \& Ndima interview, M.M. Also: Hidden Voices interviews, G.M.N, 16 June 2004.

${ }^{54}$ Pers. Comm., Nick Smith, 22 August 2015 - based on his interviews in KwaMashu and Sebokeng townships.

${ }^{55}$ PC16/12, CAP 'Background Report'.

${ }^{56}$ PC 16/12, letters to Peter Brown, 22, September 1985, 26 April 1986; 'Background report on four burglaries'; CAP Trust Report, Aug - May 1986’. Also Malan (1990).

${ }^{57}$ Particularly Bonner \& Ndima's interview with, S.M, a crucial Inkatha leader at Scaw Metals. Jeff Peires (1994) also provides an excellent account of how vigilante gangs were mobilised in the Qumbu district of Transkei.

${ }^{58}$ PC16/12, letter to Peter Brown, 13/9/93

${ }^{59}$ PC16/12, Newsletter, August 1975

${ }^{60}$ PC16/12, CAP, 'Second Report, First Grant', March 1995. CAP Newsletters, February/March 1979, March-May 1984, July 1987. CAP Annual Report, 1990

61 PC16/12, CAP Newsletter, February-March 1979

${ }^{62}$ PC16/12, CAP Newsletter, June-August 1984. Mchunu (2013: 276-7) discusses more structured reconciliation rituals led by senior women.

${ }^{63}$ PC16/12, CAP, 'Itching for a Fight' (n.d. 1982). Also: CAP Quarterly Report, December 1984 - February 1985

${ }^{64}$ PC16/12, CAP Newsletter, October 1985, June 1987

65 'PC16/12, 'Itching for a Fight'.

${ }^{66}$ PC16/12, CAP members to Archbishop Hurley, (Feb 1980?); CAP Newsletter, September 1976.

${ }^{67}$ PC 16/12 CAP Newsletter April 1980

${ }^{68}$ TRC Amnesty Hearings, Pietermaritzburg November 1999, cross-examination of Siphiwe Pearl Shandu. [Confusingly, there is no case number.]

${ }^{69}$ PC16/12, letter to P Brown, 22 September 1985

${ }^{70}$ PC16/12, CAP Newsletters, December 1976, November 1977

${ }^{71}$ PC16/12, CAP Newsletter, October 1985, April 1980

${ }^{72}$ Fieldnotes, Bizana, April 2008. Cf. Peires (2000).

${ }^{73}$ PC16/12, CAP Newsletter, September 1978

${ }^{74}$ PC16/12, CAP Newsletter, October 1985. Also: CAP Newsletters, May-November 1986, June 1987.

${ }^{75}$ Bernhardt, Dunstan Associates (1992). Bonner \& Ndima interview, V.L.

${ }^{76}$ Historical Papers, University of Witwatersrand, Shell House archive, Box A2, File 3 press clippings: especially Weekly Mail 7 June 1995, Southscan n.d.

${ }^{77}$ Elder (1995) and Xulu (2012) discuss the lives of women in township hostels. 
${ }^{78}$ Author interviews, M.Z., Soweto, 27 November 2011. Similarly: C.N., Port St Johns, 1 October 2011; M.P., Phola Park, 2 December 2011; S.N., Vosloorus, 27 October 2011

${ }^{79}$ Author interviews, M.M., Soweto, 27 November 2011; N.M., Soweto, 4 December 2011;

S.M., Soweto, 4 December 2011

${ }^{80}$ The Weekly Mail 7 June 1995 wrote that allegations about the Nqutu massacre made to the

Goldstone Commission were followed up by a Truth and Reconciliation Commission investigation, which found that 'most of the suspects were members of a hit-squad that operated from hostels in the East Rand'. The 'Independent Board of Inquiry Report, March 1994' specifically named Mlaba (also known as Mafulela). However, the final report of the TRC did not name the perpetrators. Details of the young men caught up in Mafulela's carjacking/taxi business are provided by the TRC Amnesty Hearings: Themba Stephen Zimu (AM2806/96); Nicholas Zwile Chamane (AM0188/96); and the testimony of Gertrude Mzizi, 10 December 1999. Kynoch's (2013) discussion of the Khumalo gang, which was closely associated with Mafulela, is also very useful.

${ }^{81}$ Indeed, the linkage between taxi wars and political killings was so marked that the Goldstone Commission on political violence set up a separate set of inquiries to investigate a spate of taxi killings in a series of rural towns

${ }^{22}$ TRC Amnesty Hearings, Pietermaritzburg November 1999, cross-examination of Siphiwe Pearl Shandu. [Confusingly, there is no case number.]

${ }^{83}$ Church Agricultural Project Newsletters, March 1990, June 1992

${ }^{84}$ Indeed, it is striking that none of the sources used in my article come directly from the turbulent youths at the heart of the violence, but rather articulate the concerns of chiefs, clergy, schoolteachers and other worried elders. The youths who had lived through the troubles of the 1970s and 1980s are now responsible men, and my interviews with them could only engage with their somewhat guarded reflections and memories, now shaped by their own adult concerns.

${ }^{85}$ Such writing on the Natal Midlands includes: Denis, Ntsibane \& Connell (2010), Kelly (2015), Mchunu (2013). These linked themes are especially prominent in writings about West Africa (Gore \& Pratten 2003, Richards 1998).

\section{Bibliography}

Abbink, J. and I. van Kessel eds. (2005) Vanguards of Vandals: youth politics and conflict in Africa. Leiden: Brill.

Alcock C., (1988) 'Impi’, Leadership South Africa 7 (1): 36-41.

Alcock R., (2014) 'The Curious Case of the Unknown Farmers': seminar presentation: Institute for Poverty Land and Agrarian Studies.

Anderson, D. (2002) 'Vigilantes, violence and the politics of public order in Kenya', African Affairs 101 (405): 531-55.

[A.S.S.] Anti Slavery Society (1983) Child Labour in South Africa: a general overview. Anti Slavery Society: London.

Bank, L. (1990) 'The making of the Qwa Qwa "mafia"? Patronage and protection in the migrant taxi business', African Studies 49 (1): 71-93. 
Bank L., 2011: Home Spaces, Street Styles: contesting power and identity in a South African city. London: Pluto Press.

Beinart, W. (1990) 'Migrant workers and child labour in the Natal Sugar Estates, 1913-48'. Institute of Commonwealth Studies seminar paper.

Beinart, W. (1991) 'The origins of the indlavini: male associations and migrant labour in the Transkei, African Studies, 50 (1 \& 2): 103-128.

Bernhardt, Dunstan and Associates (1992) 'The Story of a Hostel Project: A special report on Nguni Hostel at Vosloorus'. Johannesburg: Planact.

Bond, K. (1979) The Story of Mboma. Johannesburg: Ravan Press.

Bonner, P. (1987) 'The Russians on the Reef, 1947-57: urbanisation, gang warfare and ethnic mobilisation' in P. Bonner, P. Delius and D. Posel (eds.), Apartheid's Genesis, 1935-62. Johannesburg: Ravan Press.

Bonner, P. and V. Ndima (1999) 'The Roots of Violence on the East Rand, 1980-1990' Seminar Paper, Institute for Advanced Social Research: University of Witwatersrand.

Bonner, P. \& N. Nieftagodien (2001) Kathorus: a history. Johannesburg: Longman.

Bonner, P. \& N. Nieftagodien (2008) Alexandra: a history. Johannesburg: Wits University Press.

Bosch, D., D. Budlender and S. Tshabalala (2002) 'Toward a National child labour action programme for South Africa Discussion document: South African Department of Labour.

Bradford, H. (1987) A Taste of Freedom: The ICU in rural South Africa, 1924-30. (London: Yale University Press.

Campbell, C. (1992) 'Learning to Kill? Masculinity, the Family and Violence in Natal', Journal of Southern African Studies 18 (3): 614-628.

Carton B. (2000) Blood from your Children: the colonial origins of generational conflict in South Africa. Charlottesville: University Press of Virginia.

Clarke L. and J Ngobese (1975) Women without Men: a study of 150 families in the Nqutu District of KwaZulu. Durban: Institute for Black Research.

Clegg, J. (1981) 'Ukubuyisa Isidumbu - "bringing back the body": an examination of vengeance in the Msinga and Mpofana rural locations, 1882-1944' in P. Bonner (ed.), Working Papers in Southern African Studies, Vol 2. Johannesburg: Ravan Press.

Debates of the Transkei Legislative Assembly (Umtata, 1964-76)

Debates of the National Assembly, Republic of Transkei (Umtata, 1977-87) 
Delius, P. (1996) A Lion amongst the Cattle: reconstruction and resistance in the Northern Transvaal. Oxford: Currey.

Denis P., R. Ntsimane and T. Cannell (2010), Indians versus Russians: an oral history of the political violence in Nxamalala, 1987-93. Pietermaritzburg: Cluster Publications.

Elder, G. (1995) 'Apartheid, Geography and Gender: transforming South Africa's migrant worker hostels'. PhD thesis, Clark University.

Gibbs, T. (2014) 'Becoming a "Big Man" in Neo-Liberal South Africa: masculinities in the minibus-taxi industry' African Affairs, 113: 431-48.

Glaser, C. (2000) Bo-Tsotsi: the youth gangs of Soweto, 1935-1976. Oxford: Currey.

Glaser, C. (2008) 'Violent crime in South Africa: historical perspectives', South African Historical Journal, 60 (3): 334-52.

Gore, C. \& D. Pratten (2003) 'The politics of plunder: the rhetoric of order and disorder in Southern Nigeria' African Affairs 102 (407): 211-240.

Hartshorne K., (1992) Crisis and Challenge: Black Education, 1910 - 1990. Oxford: Oxford University Press.

Hickel, J. (2015) Democracy as Death: The Moral Order of Anti-Liberal Politics in South Africa. London: University of California Press.

Institute for Security Studies, 'Crime Hub'

<https://www.issafrica.org/crimehub/map/>, accessed 1 June 2015

James, D. (1983) The Road from Doornkop: a case study of removals and resistance. Johannesburg: South African Institute of Race Relations.

Jijana, T. (2013) Nobody's Business: a search for answers after a taxi murder (Mampoer Shorts: Johannesburg.

Kelly J., (2015) “"Women were not supposed to Fight”: the gendered uses of martial and moral Zuluness during uDlame, 1990-4', in J.B. Shetler (ed.), Gendering Ethnicty in African Women's Lives. Madison: University of Wisconsin Press.

Kynoch, G. 'Urban Violence Colonial Africa: A Case for South African Exceptionalism', Journal of South African Studies, 34, 3 (2008), pp.629-45.

Kynoch G., (2005) We are Fighting the World: a history of the Marashea gangs in South Africa, 1947-1999. Athens NH, Ohio University Press.

Kynoch, G. (2013) 'Reassessing transition violence: voices from South Africa's township wars, 1990-4' African Affairs 112 (447): 283-303 
la Hausse, P. (1990) "The cows of Nongoloza": youth, crime and amalaita gangs in Durban, 1900-36', Journal of Southern African Studies 16 (1):.79-111.

Lindsay L. and S. Miescher (eds) (2003) Men and Masculinities in Modern Africa. Heinemann: Portsmouth NH.

Malan, R. (1990) My Traitor's Heart. London: Bodley Head.

Marks, M. (2001) Young Warriors: youth politics, identity and violence in South Africa. Johannesburg: Witwatersrand University Press.

Mathaba, J. (2000) 'Cattle Praises of the kwaMthethwa area of Empangeni, KwaZulu Natal, as a reflection of some socio-cultural norms and values of the area'. MA thesis, Uuniversity of KwaZulu Natal.

Mathis, S. (2013), 'From warlords to freedom fighters: political violence and state formation in Umbumbulu, South Africa' African Affairs 112 (448): 421-39.

McAllister, P. and D. Deliwe 1994. 'Youth in the Transkei: the demise of traditional youth associations and the developments of new forms of association and activity: 1975-1993'. Grahamstown: Institute for Social and Economic Research Working Paper No 64.

McClendon, T. (2002) Genders and generations apart: labour tenants and customary law in segregation-era South Africa, 1920s to 1940s. London: Heinneman.

Mchunu M., 'Cultural Change, Zulu Masculinity and Intergenerational Conflict in the context of Civil War in Pietermartizburg, 1987-1991', in T Shefer, K Ratele, A Strebel, N Shabalala and R Buikema (eds.), From Boys to Men: Constructions of masculinity on contemporary society (UCT Press, 2007), pp.225-41.

Mchunu, M. (2013) 'A History of Political Violence in KwaShange, Vulindlela district and its effects on the Memories of Survivors'. PhD thesis, University of KwaZulu Natal.

Meintjes, L. (2004) 'Shoot the sergeant, shatter the mountain: the production of masculinity in Zulu ngoma song and dance in post-apartheid South Africa', Ethnomusicology Forum, 13, (2): 173-201.

Morrell, R. (2001) 'The times of change: men and masculinity in southern Africa' in R. Morell (ed.) Changing Men in Southern Africa. Pietermaritzburg: University of Natal Press.

Mpanza, Z. and J. Nattrass (1987) 'Poverty, Migration and Unemployment in Dumisa: a rural area of KwaZulu' Centre for Applied Social Sciences Working paper 10, University of Natal.

Murray C. (1980) 'Migrant labour and changing family structure in the rural periphery of South Africa' Journal of South African Studies, 6 (2): 139-56

Murray C. (1981) Families Divided: The impact of migrant labour in Lesotho. Cambridge: Cambridge University Press. 
Ndima, G. (1997) “"Ayizond' Inkabi” (An Ox Perseveres): the changing lives of migrants from the Nqutu district of KwaZulu Natal to Germiston, 1950-1980s'. PhD thesis, University of Witwatersrand.

Ndlovu, D. (1994) 'Trust in God and Weapons' South African Quarterly 1 (1): 1-24.

Niehaus, I., (2000) 'Towards a Dubious Liberation: masculinity, sexuality and power in South African lowveld schools, 1953-1999', Journal of Southern African Studies, 26 (3): 387-407

Nolte, I. (2004) 'Identity and violence: the politics of youth in Ijebu-Remo, Nigeria', Journal of Modern African Studies 42 (1): 61-89.

Ntsebza, D. (August 2005) 'Committee of Inquiry into the Underlying Causes of the Instability and Conflict in the Minibus Taxi Industry in the Cape Town Metropolitan Area: report to the premier'. Cape Town: Government Printer.

Nkosi-Thomas, L.G. \& M. Randera (2000) 'Final Report: commission of enquiry into the causes of taxi violence and related unresolved deaths in Gauteng Province'. Johannesburg: Government Printer.

Peires, J. (1994) 'Unsocial Bandits: The stock thieves of Qumbu and their enemies'. History Workshop, University of Witwatersrand.

Peires J., (2000) 'Traditional Leaders in Purgatory: local government in Tsholo, Qumbu and Port St Johns, 1990-2000 African Studies 59 (1): 97-114

Peskin M. \& A. Spiegel (1976) 'Migrant Labour Project: urban hostels in the Johannesburg area, a preliminary study’. Institute for Social and Economic Research, Grahamstown.

Platzky L. \& C. Walker (1985) The Surplus People: forced removals in South Africa. Johannesburg: Ravan Press.

Potts, D. (2010) Circular Migration in Zimbabwe and Contemporary Sub-Saharan Africa. Oxford: Currey.

Preston-Whyte E. \& S. Nene (1991) 'Black women and the rural informal sector' in E. Preston-Whyte and C. Rogerson (eds.) South Africa's Informal Economy. Cape Town: Oxford University Press.

Richards, P. (1998) Fighting for the Rainforest: war youth and resources in Sierra Leone. Oxford: Currey.

Seekings, J. (1993) Heroes or Villains. Johannesburg: Ravan Press.

Seekings, J. (2006) 'Beyond heroes and villains: the rediscovery of the ordinary in the study of childhood and adolescence in South Africa', Social Dynamics 32 (1): 1-20. 
Segal, L. (1992) 'The human face of violence: hostel dwellers speak', Journal of Southern African Studies, 18 (1): 190-231.

Sitas, A. (1983) 'African Worker Responses on the East Rand to changes in the Metal Industry, 1960-1980’. PhD Thesis, University of Witwatersrand.

Sithole J., (1998) 'Land, Officials, Chiefs and Commoners in the Izimpi Zemibango in the Umlazi Location of the Pinetown District in the Context of Natal's Changing Political Economy, 1920-1936'. M.A. thesis, University of Natal.

Spiegel, A. (1987) 'Dispersing dependants: a response to the exigencies of labour migration in rural Transkei' in J. Eades (ed.) Migrants, Workers and the Social Order. London: Tavistock.

Smith, N. (2015) 'Historical Romanticism: hoe intimacy drove popular justice in South Africa's history'. Politics and Protest Workshop paper, City University New York.

Stewart, P. (1981) 'A Worker has a Human Face: Mahlabatini, Vosloorus Hostel and an East Rand foundry: The experiences of a migrant worker'. BA Honours thesis, University of Witwatersrand.

Streek B. and Wicksteed R. (1981) Render unto Kaiser: a Transkei dossier. Johannesburg: Ravan Press.

Todes, A. (2001) 'South African Urbanisation dynamics and the normalisation thesis' Urban Forum 12 (1): 1-26.

van der Waal, C. S. (1996) 'Rural children and residential instability in the northern province of South Africa' Social Dynamics 22 (1): 31-54.

van Onselen, C. (1982) Studies in the Economic History of the Witwatersrand, vols 1 \& 2. Johannesburg: Ravan Press.

Waetjen, T. (2006) Workers and Warriors: masculinity and the struggle for the nation in South Africa. Cape Town: HSRC Press.

Waller, R. (2006) 'Rebellious Youth in Colonial Africa', Journal of African History, 47 (1): 277-92.

Xeketwane, B.M. (1991) 'The War on the Reef: The Political Violence on the reef's Black Townships since July 1990’. BA Honours thesis, University of Witwatersrand.

Xeketwane, B.M. (1993) 'The relation between hostels and the political violence on the reef from July 1990 to December 1993: A case study of Merafe and Meadowslands hostels in Soweto'. MA thesis, University of Witwatersrand.

Xulu, N. (2012) 'Changing Migrant Spaces and Livelihoods: Hostels as community residential units, KwaMashu, KwaZulu Natal'. PhD thesis, University of Cape Town. 